\title{
The Impact of Export and Import to Economic Growth of Ghana
}

\author{
Isaac Okyere* \\ Liu Jilu \\ Business school, Taizhou University, Taizhou, China
}

School of Economics and Management, Zhejiang University of Science and Technology; Hangzhou, China

\begin{abstract}
International trade is a cross-border exchange of goods and services. It is the commonest form of international trade activity, which has been instrumental in modifying world history. The overall objective of this study is to identify and quantify the impacts of exports and imports on Ghana's economic growth from 1998 to 2018. Through the unit root and cointegration test, through the first-order difference cointegration variable stability and long-term equilibrium relationship. There is no significant causal relationship between imports in international trade and Ghana's GDP growth. Exports have a significant causal relationship with Ghana's GDP growth, such as cocoa. The exchange rate and inflation rate are not Granger causal causes of GDP. Conversely, GDP is indeed the Granger causal cause of exchange rate and inflation rate.
\end{abstract}

Keywords : Impact; Export; Import; Economic growth; Ghana.

DOI: $10.7176 / \mathrm{EJBM} / 12-21-15$

Publication date:July $31^{\text {st }} 2020$

\subsection{INTRODUCTION}

International trade is a cross-border exchange of goods and services. It is the commonest form of international trade activity; it has played an important role in modifying history of the world. This is also the first form of foreign business activity that most businesses conduct, since importing or exporting requires the least effort and risk to the resources of the organization. Development economists took an interest in the importance of international trade in the process of development. International trade enables producers and retailers to search for foreign-produced goods, facilities, and parts. A nation can not only rely on the products they manufacture domestically but turn to products elsewhere. Popular traditional trade theories such as the absolute advantage and comparative advantage make the concept of trade simple by stressing the importance of trade. Countries are considering reducing imports through programmes such as the import substitution strategy, in order to promote locally produced goods. Many underdeveloped countries, to which Ghana is no exception, have adopted this strategy for import substitution but, unfortunately, it has not been as expected for them. Ghana adopted policies aimed at industrialization and the replacement of imports by domestic production, resulting in problems with the balance of payments

\subsection{STATEMENT OF PROBLEM}

Analysis of the empirical literature on the link between foreign trade and economic development shows that very few studies are available on Ghana. Among these studies is Chanthunya (1991) who analyzed the nexus of exportgrowth in several ECOWAS countries, including Ghana. He found that the export-to-GDP relationship is positive but still weak. The conflicting findings obtained in the above studies clearly indicate that the link between foreign trade (exports and imports) and economic growth in Ghana is a gap in knowledge. This study aims to help bridge this empirical knowledge gap by examining the effect of exports and imports on Ghana's economic growth in isolation, rather than as part of a bloc of Sub-Saharan African countries. In comparison to previous empirical studies on the topic that focused primarily on exploring the existence of correlation between the two variables, this research focuses on establishing the existence of a long-term balance link between exports and economic development. It is only the existence of a long-run link between the two variables that guarantees sustainable economic development.

\subsection{SIGNIFICANT OF THE STUDY}

It is an unquestionable fact that every economy's goal is to achieve the highest level of growth possible. A rise in growth typically means an increase in people's aggregate welfare. This is why, over the years, governments of developed countries have pursued policies that would lead to development. Obviously, the role of international goods and services movement as well as growth factors cannot be overemphasized.

Consequently, the study will be of significant help to Ghana's policymakers in deciding whether or not the country should continue with the trade-led economic growth agenda or pursue a completely different economic development. This paper will also serve as a critical guide for researchers in the field of development economics conducting further work on the topic in Ghana as well as beyond. 


\section{LITERATURE REVIEW}

\subsection{Impact of Export on Economic Growth}

Export-led growth hypothesis testing was performed during 1971-2016 periods using Pakistan as a case study empirically investigated. By adopting the study of cointegration and the dynamic error correction mechanism, it has been shown that exports are very important determinants of Pakistan's economic growth. The study also finds that exports to the private sector with labour, production, and domestic credit are also significant in Pakistan's short- and long-term economic growth (Fatemah \& Qayyum, 2018). Time series econometric cointegration techniques and vector error correction estimation was used to analyze the effect of exports on Ghana's economic growth using yearly data of 1980 to 2013. Johansen 's cointegration test revealed the existence of a long-term relation between real GDP, exports, gross development, and labour in Ghana, and further evidence shows that there is bidirectional causality between exports and GDP growth using Granger causality test (Tetteh, 2015). The study sought to explore long-term and short-run link between exports and gross domestic product (GDP) according to Tetteh (2015) time series econometric techniques of cointegration and vector error correction estimation. Cointegration test by Johannsen revealed the presence of long-term link in Ghana between real GDP, exports, gross capital creation, and labour. There was also proof of two-way causality between exports and growth of GDP using Granger causality test.

\subsection{The Impact of Import to Economic Growth}

Annual data between the 1990-2015 periods has been evaluated to evaluate the link between imports and economic growth in Canada using the co-integration study of the Vector Auto Regression Model and the Granger-Causality measures. The results suggest that there is no connexion between imports and economic growth in Canada, as well as clear evidence of bidirectional causality from imports into economic growth and evidence that imports are seen as the cause of economic growth in Canada (Sayef, 2016). Annual data for the period 1980-2015 was analysed to examine the relationship between imports and economic growth in Canada using Johansen's co-integration study of the Vector Auto Regression Model and Granger-Causality studies. The results indicate that there is no association between imports and economic growth in Canada, as well as clear proof of bidirectional causality from imports to economic growth and proof that imports are perceived to be the cause of economic growth in Canada (Bakari \& Mabrouki, 2017). The link between imports and economic growth in South Korea was evaluated using the $\log$ difference to calculate Solow residual, and the results were obtained using the quarterly data from 19802003. The findings show that imports have a substantial positive effect on economic growth by having a major impact on sustainable growth (Kim, Lim, \& Park, 2007).

\section{ANALYSIS OF GHANA'S INTERNATIONAL TRADE AND ECONOMY \\ 3.1 Import Analysis}

Total imports of Trend Ghana suggest that, over the years, import trade has soared overall. The import sector in Ghana plays a major role in offsetting the short fall in domestic supply in terms of capital and intermediate goods as well as the ever-increasing demand for imported goods by consumers. A total of goods worth $\$ 1,318$ million were imported into the country in 1991, compared to imports worth $\$ 1,204.96$ million in 1990 , indicating a rise of around 9.4 percent. Import trade in Ghana has improved over the years, resulting in total imports to the country reaching \$4.297.8 million in 2004, up 32 per cent compared to total imports in 2003 of \$3.232.82 million. The import market continues to expand as the economy shifts toward further expansion, and this is proof of remarkable growth in import trade as overall imports of the country rose to $\$ 6,753.68$ million in 2006 compared to $\$ 5,347.31$ million in 2005, reflecting a $26.3 \%$ growth rate. Furthermore, the overall import trade in Ghana increased significantly in 2011 by 46.2 percent to $\$ 15,968.40$ million compared to $\$ 10,922.11$ million in 2010 . The trend analysis indicated that Ghana's import trade between 1990-2011 increased by an average of 14.50 percent, suggesting good performance over the comparison period relative to the sub-Saharan average 3.2 Ghana Major Product Imports Ghana product imports are dominated by manufactured products, which represented an annual average e of $65 \%$ over the period recorded, followed by fuel $(17 \%)$ and all food items $(6 \%)$. The rate at which the component of the manufactured goods had grown is following a similar trend as the total import.

As for import services, transport services account for an average of 44 percent of total service imports, followed by other services, except for travel services, since they account for 15 percent of total service imports. While transport services have contributed to a large proportion of Ghana's service imports, over the years, they have grown slower than the other services.

Over the period 1995 to 2014, the main merchandise imports were petroleum products, bitumen, minerals and crude oils, accounting for 9 percent of the world 's total merchandise imports into Ghana. The nation is trading with emerging as well as developed countries. Ghana imported most of its import goods from developing countries during the period 1995 to 2002 . After 2002, however, imports from developing countries began to increase, while imports from developed countries began to decrease. 


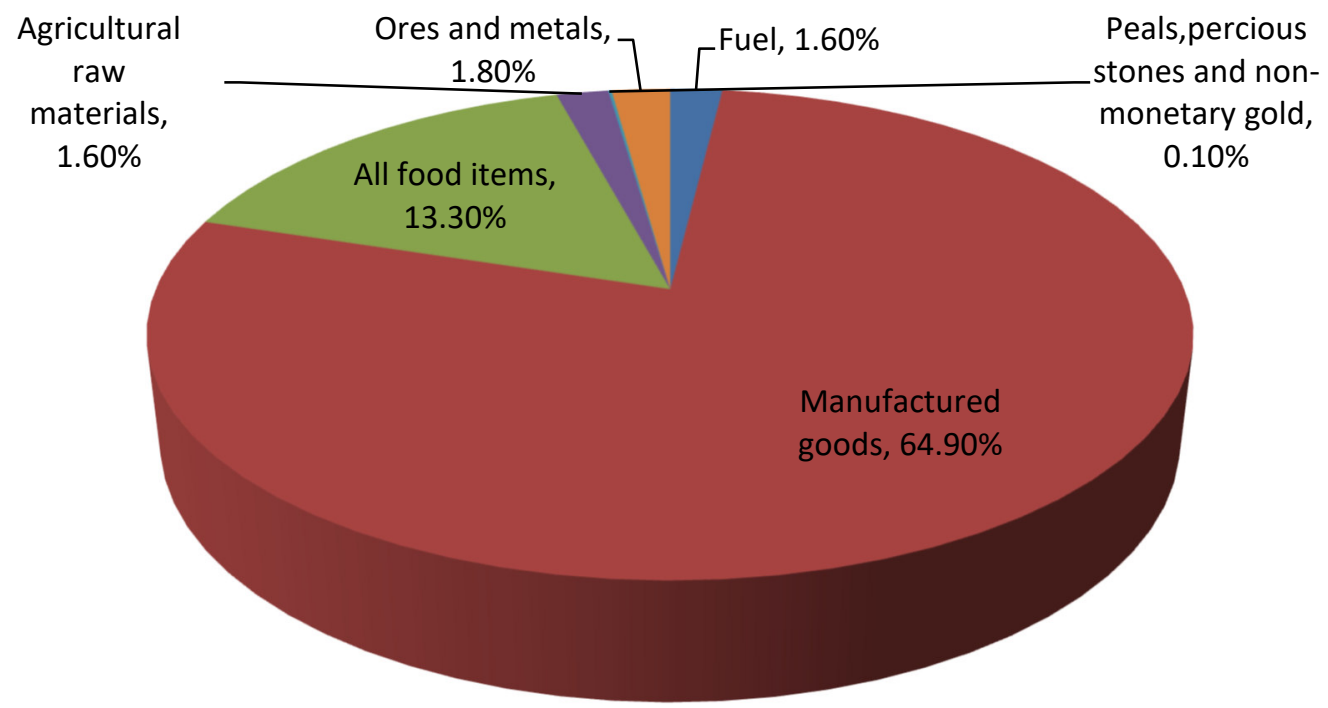

Figure 1. Average annual composition of Ghana's imports by major product group (1995-2014) Source: Nomfundo, 2017.

\subsection{Export Analysis}

Exports are of great importance for the economy of any country. Influencing the expenditure balance, jobs, and rates of economic development. Including domestic trade and economic prosperity. Export growth is tied to distribution of employment, wealth and economic development.

In Ghana, exports of commodities were divided into traditional and non-traditional exports (NTEs). Traditional exports consist mainly of primary commodities or raw materials, including cocoa beans, minerals (gold, diamond, bauxite, and manganese), wood and fresh fish. Many other exports, such as handicrafts, aluminum products, and horticultural products (GEPC, 1986), are non-traditional exports (NTE). Non-traditional exports (NTEs) are considered a major means of poverty reduction, especially in Ghana's rural communities, due to their great potential to create jobs and generate income.

Four major sub-sectors power the non-traditional export sector (NTEs): non-traditional agricultural commodities, processed and semi-processed goods, crafts and services. Non-traditional agricultural resources are classified into horticulture, fish products, game and wildlife and other primarily fresh fruits such as pineapples, mangoes, medicinal seeds and plants, tropical flowers, and vegetables such as okra, tinda, and marrow. These include yam, natural rubber, cotton seeds, kola nuts, corn, coconuts, assorted fruits, and lobsters / shrimps / prawns. The processed and semi-consumer products are often made up of wood products, imported goods such as pharmaceuticals, electric cables and aluminum products, canned foods and drinks, and other processed products. Handicraft consists primarily of carving, weaving, woodworking and ornamental items such as beads and jewellery. Resources also provide tourism drugs, financial services, and education (GEPA, 2013). Processed and semiprocessed products contribute approximately 90 per cent of sales, while the remainder consist of agriculture and non-traditional commodities and handicrafts. Processed and semi-processed foods toped the sub-sectors in 2012 with US\$ 2.110 .03 million followed by agriculture with US\$ 306.11 million and handicrafts with US\$2.46 million.

In 2012, cocoa paste, cashew nuts, plastic articles, and canned tuna took the top four spots of Non-traditional exports. Others included veneers, natural rubber sheets, feed for animals, medicinal plants, aluminum sheets and iron / steel products (GEPA, 2013).

\subsection{Trends in Exports, Key Export Commodities and Composition of Exports in Ghana}

Political mismanagement, a widespread coup d'état resulting in political turmoil and an adverse foreign economic climate laid the ground for economic retrogression in the 1970s and early 1980s. "With relatively high GDP growth in the 1950s and early 1960s, as of 1964, the Ghanaian economy began to experience a decline in GDP growth. For most of the time after the mid-1960s, development was unstable and only started to stabilise by 1984 . The growth rate was negative in the years 1966, 1972, 1975-1976, 1979, 1980-1983. The years in which negative growth occurred usually correspond with changes in government and often with changes in policy or reversals (Fosu, 2002).

The Ghanaian government effectively rehabilitated major economic industries, which had collapsed since the 1960s, in the late 1980s. The launch of the Economic Recovery Program (ERP) in 1983 made this possible to a 
significant degree. A major aspect of the ERP was the implementation of an outward-oriented growth policy as a primary avenue to reduce the current-account deficit the country faced at the time.

In particular, by the early 1990s the export sector regained some strength with resurgence in exports of cocoa, gold and timber. However, the Government turned its focus to the desirability of non-traditional exports in its quest to encourage export diversification. Non-traditional exports (NTEs) are significant because of the role that export diversification plays in promoting economic recovery (Oduro et al,1992). Over the past three decades Ghana 's exports have risen significantly. Exports from the country increased from US\$ 635 million in 1986 to US\$14,377 million in 2011 (WTO, 2012); reflecting an average annual export growth of 70 per cent over the period. Table 2 shows total export values and the contributions of the three key traditional export commodities to export earnings in Ghana as well as Non-Traditional Exports (NTEs) and others (cash crops, fish products and aluminum products). From Table 2, it can be seen that cocoa and gold have been the two most important export commodities in Ghana over the years. In particular, by the early 1990s the export sector regained some power with a rebound in exports of cocoa, gold and timber. The government has, however, turned its focus to the desirability of non-traditional exports in its attempt to encourage export diversification. The value of non-traditional exports (NTEs) lies in the role that diversification of exports plays in fostering economic recovery (Oduro et al., 1992). Over the last three decades Ghana's exports have increased significantly. Exports from the country grew from US\$ 635 million in 1986 to US\$ 14,377 million in 2011 (WTO, 2012); reflecting an average annual export growth of 70 percent over the period. Cocoa yields dominated Ghana's export market. Nevertheless, over the years, this sector 's dominance has started to decline as Ghana increased its export base. The share of Cocoa's export earnings gradually declined from $67 \%$ in 1986 to $20 \%$ in 2001. It then seems to have picked up again in 2004 to 38 percent, and then decreased again in 2011 to 23 percent (Table 2). Throughout the years, NTE and other contributions (cash crops, fish products, and aluminum products) including cocoa to total export earnings have increased. NTEs and others' earnings have gradually grown from 10 percent in 1986 to 37.1 percent in 2011 (Table 1). At the other hand, timber export earnings rose from 6\% in 1986 to $14 \%$ in 1993. Yet the contribution of timber export earnings to Ghana's total exports dropped slowly from 14 percent in 1994 to 1.9 percent in 2011 due to continued deforestation and lack of replacement of harvested timber over the years.

\begin{tabular}{|c|c|c|c|c|c|}
\hline Years & $\begin{array}{l}\text { Total } \\
\text { Exports }\end{array}$ & $\begin{array}{l}\text { Cocoa pro. \& } \\
\text { Marketing (\%) }\end{array}$ & $\begin{array}{l}\text { Gold } \\
(\%)\end{array}$ & $\begin{array}{l}\text { Timber } \\
(\%)\end{array}$ & $\begin{array}{l}\text { Non-traditional } \\
\text { and others }(\%)\end{array}$ \\
\hline 1986 & 635 & 67 & 17 & 6 & 10 \\
\hline 1987 & 827 & 60 & 19 & 11 & 10 \\
\hline 1988 & 908 & 52 & 21 & 13 & 14 \\
\hline 1989 & 865 & 51 & 23 & 10 & 16 \\
\hline 1990 & 897 & 40 & 22 & 13 & 25 \\
\hline 1991 & 999 & 35 & 30 & 12 & 23 \\
\hline 1992 & 986 & 31 & 35 & 12 & 22 \\
\hline 1993 & 1064 & 27 & 41 & 14 & 18 \\
\hline 1994 & 1238 & 26 & 44 & 13 & 17 \\
\hline 1995 & 1431 & 27 & 45 & 13 & 15 \\
\hline 1996 & 1571 & 35 & 39 & 9 & 17 \\
\hline 1997 & 1490 & 32 & 39 & 12 & 17 \\
\hline 1998 & 2091 & 30 & 33 & 8 & 29 \\
\hline 1999 & 2005 & 28 & 35 & 9 & 28 \\
\hline 2000 & 1936 & 23 & 36 & 9 & 32 \\
\hline 2001 & 1867 & 20 & 33 & 9 & 38 \\
\hline 2002 & 2064 & 23 & 33 & 9 & 35 \\
\hline 2003 & 2297 & 36 & 36 & 8 & 20 \\
\hline 2004 & 2704 & 38 & 31 & 8 & 23 \\
\hline 2005 & 2802 & 32 & 34 & 8 & 26 \\
\hline 2006 & 3365 & 36 & 41 & 9 & 14 \\
\hline 2007 & 3216 & 25 & 47 & 8 & 20 \\
\hline 2008 & 5181.7 & 27 & 43 & 6 & 24 \\
\hline 2009 & 5882.1 & 32 & 43 & 3.06 & 21.04 \\
\hline 2010 & 7960.09 & 25 & 48.2 & 2.3 & 24.5 \\
\hline 2011 & 14377 & 23 & 38 & 1.9 & 37.1 \\
\hline
\end{tabular}

Source: Bank of Ghana, 2012.

Table 1: Export Earnings and Percentage Contribution of Key Commodities to Export Earnings, 19862018 (Real 1987 million US dollars) 


\section{Research Design}

\subsection{Data Collection}

This research utilized data obtained from the secondary annual time series for the period 1998 to 2018. This secondary yearly time series data was obtained from the Ghana Statistical Service (GSS), Ghana Export Promotion Authority (GPA), World Bank, Bank of Ghana, World Development Indicators, Food and Agricultural Organization on GDP, exports, imports, exchange rates and inflation. These were chosen not only because of their credibility but also because of their comprehensive record keeping of these variables in the statistics. Annual time series data were selected because data on the above variables is normally collected annually in Ghana. Therefore, collecting annual instead of monthly or quarterly time series is simpler. However, because the Ghana Statistical Service (GSS), the Ghana Export Promotion Authority (GPA), the World Bank, the Bank of Ghana, the World Development Indicators, the Food and Agriculture Organization is free and available to the public, data could be easily accessed as there was no need to request prior authorization.

\subsection{Methodology}

The research used in the study covers the 1998 to 2018 annual time series, or 36 observations that should be adequate to capture the model's short-term and long-term correlation between export, import and economic development. The data collection consists of measurement for GDP, goods and services exports (US\$ currency), and goods and services imports (US\$ currency). Both sets of data are taken from 2014 Global Development Indicators. The methodology of estimation employed in this analysis is the simulation technique of co-integration and error correction. The whole estimation process consists of five steps: first, root unit test, second, co-integration test, third, causality of the Granger and fourth, VAR stability model.

\subsection{Variable design}

The following are the variables used in the paper, GDP is the variable of economic growth, and the trade variables include Export, Cocoa, Import, Gold, and Exchange Rate, Inflation Rate.

\begin{tabular}{|l|l|l|}
\hline Variable & Code & Definition \\
\hline GDP & gdp & The growth rate of GDP of Ghana \\
\hline Export & export & Total exports \\
\hline Cocoa & cocoa & Ghana's main cash crop \\
\hline Import & import & Total imports \\
\hline Gold & gold & A chemical element with symbol Au (from latin: aurum) \\
\hline Exchange Rate & ex_rate & Value of one country's currency in relation to another currency \\
\hline Inflation Rate & in_rate & Price increase in Ghana \\
\hline
\end{tabular}

\subsection{Research Model Construction}

This study aims to establish an economic model that will provide a deeper understanding of the relationship between international exchange and economic growth that exists in the Ghanaian economy. The basis for formulating the research will be Erhieyovwe and Onokero (2013). There are three variables in their model: GDP as an independent variable, and production and exchange rates as regressions. The research used the same variable and more variable, such as import and inflation rates, are used as other determinants of foreign trade in Ghanaian economy. The study estimates the growth model which can be expressed in it function forms as follows:

$$
G D P=f(\text { export,cocoa,import,gold,ex_rate,in_rate).......... (i) }
$$

\section{Results and interpretation}

\subsection{Unit Root Test}

Stationarity test is also called unit root test. When there is unit root in a time series, the sequence is not stationary. In order to remove the unit root, we generally make a difference to the time series, so that the time series stationary. First, the unit root test is performed on the model's time series to verify if it is stable. We take inspection system ADF in this report.

We take the normal logarithm to remove the effect of changing variables on units and patterns. The unit root test result for each variable is as follows. As can be seen from the table 3, each variable's time series isn't stable. 


\begin{tabular}{|l|l|l|l|l|l|l|}
\hline Variable & $\begin{array}{l}\text { ADF } \\
\text { Statistics }\end{array}$ & $\mathbf{( c , t , p )}$ & $\begin{array}{l}\mathbf{1 \%} \\
\text { Critical } \\
\text { value }\end{array}$ & $\begin{array}{l}\mathbf{5 \%} \\
\text { Critical } \\
\text { value }\end{array}$ & $\begin{array}{l}\mathbf{1 0 \%} \\
\text { Critical } \\
\text { value }\end{array}$ & Conclusion \\
\hline Lngdp & -0.995 & $(\mathrm{c}, 1,0)$ & -4.343 & -3.584 & -3.23 & Unstable \\
\hline lnimport & -1.548 & $(\mathrm{c}, 1,0)$ & -4.343 & -3.584 & -3.23 & Unstable \\
\hline Lngold & -1.878 & $(\mathrm{c}, 1,0)$ & -4.343 & -3.584 & -3.23 & Unstable \\
\hline lnexport & -0.719 & $(\mathrm{c}, 0,0)$ & -3.723 & -2.989 & -2.625 & Unstable \\
\hline lncocoa & -0.048 & $(\mathrm{c}, 0,0)$ & -3.723 & -2.989 & -2.625 & Unstable \\
\hline ex_rate & 0.526 & $(\mathrm{c}, 1,0)$ & -4.343 & -3.584 & -3.23 & Unstable \\
\hline in_rate & -1.543 & $(0,1,0)$ & -2.654 & -1.95 & -1.602 & Unstable \\
\hline
\end{tabular}

Source: Author's compilation from stata.

Table 3: ADF test results

In order to obtain a stable time series, this paper achieves it through the first differencing transformation without changing the causality between variables.

From Table 4, we can see that after the first-order difference conversion, all variables have passed the ADF test, indicating that the first-order differences of all variables are stable and can be analyzed later.

As we can see from table 4 , the ADF value corresponding to $\triangle \operatorname{lnGDP}$ is -4.425 , and the negative value is less than the critical value of -2.654 at the $1 \%$ confidence level, which leads to the rejection of the null hypothesis at the $1 \%$ confidence level, which means the unit root is rejected and $\Delta \ln$ GDP is a stationary series.

\begin{tabular}{|l|l|l|l|l|l|l|}
\hline & $\begin{array}{l}\text { ADF } \\
\text { Statistics }\end{array}$ & $\mathbf{( c , t , p )}$ & $\begin{array}{l}\mathbf{1 \%} \\
\text { Critical } \\
\text { value }\end{array}$ & $\begin{array}{l}\mathbf{5 \%} \\
\text { Critical } \\
\text { value }\end{array}$ & $\begin{array}{l}\mathbf{1 0 \%} \\
\text { Critical } \\
\text { value }\end{array}$ & Conclusion \\
\hline$\triangle$ lngdp & -4.425 & $(\mathrm{c}, \mathrm{t}, 0)$ & -2.654 & -1.95 & -1.602 & Stable \\
\hline$\triangle$ lnimport & -6.312 & $(\mathrm{c}, \mathrm{t}, 0)$ & -3.723 & -2.989 & -2.625 & Stable \\
\hline$\triangle$ lngold & -5.674 & $(\mathrm{c}, \mathrm{t}, 0)$ & -3.723 & -2.989 & -2.625 & Stable \\
\hline$\triangle$ lnexport & -7.333 & $(\mathrm{c}, \mathrm{t}, 0)$ & -3.723 & -2.989 & -2.625 & Stable \\
\hline$\triangle$ lncocoa & -7.02 & $(\mathrm{c}, \mathrm{t}, 0)$ & -3.723 & -2.989 & -2.625 & Stable \\
\hline$\triangle$ ex_rate & -5.844 & $(\mathrm{c}, \mathrm{t}, 0)$ & -4.343 & -3.584 & -3.23 & Stable \\
\hline$\triangle$ in_rate & -6.108 & $(\mathrm{c}, \mathrm{t}, 0)$ & -3.73 & -2.992 & -2.626 & Stable \\
\hline
\end{tabular}

Source: Author's compilation from stata

Table 4: ADF test results for first differencing

\subsection{Co-integration Test}

By conducting the cointegration test, we can further reveal whether there is a long-term equilibrium relationship among these economic variables. In the above, we have adjusted all non-stationary variable data to the first order single integer time series.

The co-integration test is divided into two steps: first, first perform OLS regression on the independent variables of lngdp and save the regression residuals; second, perform unit root test on the time series residuals.

This paper selects the E-G test in the cointegration test to explore whether there is a long-term equilibrium relationship between the market concentration of the banking industry and economic growth. Next, we use Eviews software for E-G test to determine the equilibrium relationship between economic growth (GDP) and international trade. First, we make OLS estimates of lngdp and various variables of international trade, and obtain the following equations:

$$
\begin{gathered}
\text { Lngdp }=2.2215+0.3547 * \text { lnimport } \\
\text { Lngdp }=2.7007+0.3331 * \text { lngold } \\
\text { Lngdp }=2.3788+0.3471 * \text { lnexport } \\
\text { Lngdp }=2.8123+0.3392 * \text { Incocoa } \\
\text { Lngdp }=4.2376+060.6191 * \text { ex_rate } \\
\text { Lngdp }=5.8393-4.3532 * \text { in_rate }
\end{gathered}
$$

From the above results the relationship between GDP and import is positive. A $1 \%$ export shift would raise GDP by 0.355 and is important and 1\%. This argument is in line with Nguyen (2016), who mentions that exports to the private sector with labour force, investment and domestic credit are also important in Pakistan's short- and long-term economic development. At 1\% level of significance, a unit change in gold will increase GDP by 0.333 , indicating a direct relationship between GDP and Gold. This is because through foreign investment people can invest in gold and that can increase the country's GDP. This justification is in line with Thomas, (2018), who stated that gold has a direct relationship with GDP. 
Export is significant at $1 \%$, implying that a unit change in export will increase GDP by 0.347 . Indicating a positive relationship between export and GDP. This is true in the sense that if a country exports more of its goods and services, the higher the capital inflow which in effect increases GDP. This assertion is in line with Fatemah \& Qayyum, (2018), who stated that there is a positive relationship between export and GDP in canada.

Cocoa is also significant at $1 \%$, indicating that a unit change in cocoa will increase GDP by 0.339 . Showing a positive relationship between cocoa and GDP. Basically, cocoa is an international commodity that has always been in high demand, therefore it will make sense that any country that's produces more cocoa will me more likely to increase its GDP, since its demand is always high. This assertion contradicts with the findings of Sayef, (2016), who mention that there is a negative relationship between cocoa and GDP.

There is a positive relationship between exchange rate and GDP, at 1\% significant level, a dollar change in the exchange rate will increase GDP of the country by 60.619. This assertion is in line with Soja, (2016), who mention that there is a positive relationship between exchange rate and GDP.

However, at $1 \%$ level of significance, a unit change in the inflation rate will decrease GDP by -4.353 . This implies that there is a negative relationship between inflation rate and GDP. This justification conforms to Fischer (1993), who mentions that inflation has a negative relationship with GDP.

Then perform the unit root test on the residual sequences obtained above and get Table 5 .

\begin{tabular}{|l|l|l|l|l|l|}
\hline & ADF Statistics & $1 \%$ Critical value & $5 \%$ Critical value & $10 \%$ Critical value & Conclusion \\
\hline e_import & -4.437 & -3.73 & -2.992 & -2.626 & stable \\
\hline e_gold & -4.219 & -3.73 & -2.992 & -2.626 & stable \\
\hline e_export & -4.484 & -3.73 & -2.992 & -2.626 & stable \\
\hline e_cocoa & -4.386 & -3.73 & -2.992 & -2.626 & stable \\
\hline e_ex_rate & -3.79 & -3.73 & -2.992 & -2.626 & stable \\
\hline e_in_rate & -4.553 & -3.73 & -2.992 & -2.626 & stable \\
\hline
\end{tabular}

\section{Table 5: Unit root test of residual}

From the data in Table 5, we can see that all residual sequence ADF tests are less than the critical value of $1 \%$ level, indicating that the residual sequence is stable. It shows that there is a long-term equilibrium relationship between various variables

\subsection{GRANGER CAUSALITY RESULTS}

In order to further explore the possible causal relationship between the two, we use Granger causality test to empirically analyze the causal relationship between Ghana's economic growth and international trade.

Before the Granger causality test, we must ensure that the time series being tested must be stationary. According to the results of the cointegration test, the adjusted Ghana's international trade has a long-term equilibrium relationship with economic growth and meets the conditions of the Granger test. Therefore, we first construct a binary variable autoregressive model to study the relationship between variables such as international trade and economic growth. The test results are as follows:

It can be seen from the test results that when the causality test between GDP and import is performed, the P value is 0.168 , which means that at a confidence level of $10 \%$, the original hypothesis that "lnimport is not the Granger cause of lngdp" cannot be rejected; second, the P value in the line is 0.270 , and the original hypothesis that "lngdp is not a Granger cause of lnimport' cannot be rejected. Therefore, it can be stated that there is no longterm causal relationship between GDP and import.

Gold has an impact on GDP in the long run, and the same also holds true for GDP and gold, which are important at 10 per cent and respectfully 1 per cent. That is because people will invest in gold through international investment over the long term. That result is consistent with Mabrouki(2017).

There is a causal association between export and GDP in the long run, and thus the null hypothesis is rejected at a level of 1 percent importance, while GDP has no effect on export, so we do not reject the null hypothesis. That argument is consistent with Nyasulu (2013).

It can be seen from the test results that when the causality test between GDP and cocoa is performed, the P value is 0.066 , which means that at a confidence level of $10 \%$, the original hypothesis that "Incocoa is not the Granger cause of lngdp" is be rejected; Second, the P value in the line is 0.187 , and the original hypothesis that 'Ingdp is not a Granger cause of lncocoa' cannot be rejected.

Exchange rates do not have long-term causality with GDP, but we reject the null hypothesis that GDP has a long-term causality on exchange rates at 5 per cent level. This statement is in line with Bakari (2017).

Inflation rate has no long run causality with GDP, however at $10 \%$ GDP has a long run causality with inflation. This assertion is in line with Phillips (1998). 


\begin{tabular}{|l|c|c|c|}
\hline Null hypothesis & Lag period & Chi-sq Value & P Value \\
\hline lnimport is not the Granger cause of lngdp & 4 & 6.4435 & 0.168 \\
\hline lngdp is not the Granger cause of lnimport & 4 & 0.1683 & 0.27 \\
\hline lngold is not the Granger cause of lngdp & 4 & 8.2986 & 0.081 \\
\hline lngdp is not the Granger cause of lngold & 4 & 15.271 & 0.004 \\
\hline lnexport is not the Granger cause of lngdp & 4 & 13.54 & 0.009 \\
\hline lngdp is not the Granger cause of lnexport & 4 & 5.5602 & 0.234 \\
\hline lncocoa is not the Granger cause of lngdp & 4 & 8.8125 & 0.066 \\
\hline lngdp is not the Granger cause of lncocoa & 4 & 6.1701 & 0.187 \\
\hline ex_rate is not the Granger cause of lngdp & 4 & 6.4369 & 0.169 \\
\hline lngdp is not the Granger cause of ex_rate & 4 & 12.384 & 0.015 \\
\hline in_rate is not the Granger cause of lngdp & 4 & 7.226 & 0.124 \\
\hline lngdp is not the Granger cause of in_rate & 4 & 12.121 & 0.016 \\
\hline
\end{tabular}

\section{Table 6: Granger's causality test}

\section{Conclusions and Policy Recommendation}

The study analyzed Ghana's economic growth impact of exports and imports. And four priorities to be tackled. The first is calculating the percentage of economic growth adjustment as a result of export changes. The second is to calculate the percentage of economic growth adjustment as a result of import transition. The third is to determine the relationship between exports, imports and economic growth over the long term. Finally, in assessing economic growth, the interrelationship between exports, imports, inflation and exchange rates is to be examined. This paper employs the Auto Regressive Distributed Lag Model (ARDLM) to examine the impact of international trade on economic growth of Ghana. This paper explores the effect of foreign trade on Ghana's economic growth using the Auto Regressive Distributed Lag Model (ARDLM). To test for stationarity the analytical techniques of ADF and PP were performed. Not all variables were stationary at rates, but at first difference, they were stationary.

The findings show that there is no significant causal relationship between imports in international trade and Ghana's GDP growth. This shows that imports cannot drive Ghana's domestic economic development, and that there is a mutual causal relationship between the re-import of deep-processing gold for export and GDP.

Exports in international trade have a significant causal relationship with Ghana's GDP growth, such as cocoa. This shows that the growth of exports can drive Ghana's domestic economic development and increase GDP.

The exchange rate and the inflation rate are not Granger causal causes of GDP. In turn, GDP is indeed the Granger causal cause of exchange rates and inflation rates. This posits that GDP has influence on exchange rate and inflation rates in Ghana and this can be explained by the transmission mechanism: when GDP increases it means the economy is in good shape and there are a lot of money in the system that drives demand of goods and when demand exceeds supply, the price moves upward which cause inflation in the country. Ghana is known to be import driven country and when demand increases it leads to high import of goods and that put pressure on the local currency leading to depreciation of the local currency.

The analysis looked at the effect of exports and imports on Ghana's economic development. The results show that exports are positively to GDP, while imports have a negative impact on GDP. Such findings are in line with Erhieyovwe and Onokero (2013) who maintained that the amount of exports for foreign trade is highly important. Exports have the potential to build development and infrastructure expansion in the Ghanaian economy on the basis of our empirical results. A cause for concern is the negative relationship between GDP and inflation, because it has a significant effect on trade. The rate of growth in Ghana's economy has evidently slowed in the second quarter of 2000. In view of this, the government needs to reinforce, help and promote export competitiveness by ensuring that it maintains a fair balance with imports. The unstable currency which has a negative effect on economic growth needs to be given serious attention. Therefore, its output in relation to the currencies of other developed economies needs to be monitored.

China has been the obvious destination of Ghanaian businessmen and women to import goods into the country and I strongly recommend the two countries to have easy and direct convertibility of currency in order to reduce the pressure on demand for dollar currency in order to purchase goods from China.

Finally, I recommend Chinese bank to be established in Ghana that will ease the stress of businessmen that import goods from China. The Chinese bank in Ghana shall facilitate payment of goods in China for Ghanaian businessmen without necessarily demanding physical dollar currency for payment of goods in China. In doing this, pressure of demand for dollar currency in Ghana will be reduced and the Ghanaian currency shall be valued reasonably.

\section{REFRENCES}

Ahsan, A., Mkwezalamba, M.M., Machinjili, C. and Raparla, T (2001). "The Impact of Trade Policy Reforms on 
Malawi’s Manufacturing Sector”. World Bank Report. p.4-9.

Akeem, U. O. (2011). Performance Evaluation of Foreign Trade and Economic Growth in Nigeria. Research Journal of Finance and Accounting, Vol.2, No. 2.

Bank of Ghana (2012). Annual report of the Central Bank of Ghana. ISSN: 0855-0972.

Balassa, B. (1978). "Exports and Economic Growth: Further evidence". Journal of Development Economics vol.11.p.133-137.

Carbaugh, R.J. (2005) International Economics. New York, Addison Wesley.

Chanthunya, C.I. (1991) "Trade Regime and Economic growth: special reference to Zambia and Malawi". Unpublished Ph.D. Thesis, University of Wales.

Enu, P., Dodzi, k. H., \& Edmond, H. (2013). The Impact of Foreign Trade on Economic Growth in Ghana. The Impact of Foreign Trade on Economic Growth in Ghana.

Fosu, A.K. (1990). "On Export composition and the impact Exports on Economic Growth of Developing Countries". Economic Letters vol.8. p.64-68.

Fosu, A. K. (2002). Emerging Africa: The Case of Ghana.

Fusfeld. (1990). The World Book Encyclopedia.

Gerber, J. (2007). International Economics. 4th edition. Pearson Addison Wesley, New York. .

Ghana Export Promotion Authority (2014). Developing Regional Export Trade in Ghana.

Ghana Export Promotion Council (1987). The 3-year Non-Traditional Export Development Plan, 1988-1990, Executive Summary.

Ghana Export Promotion Council (GEPC), (1987-2009). Comparison of Export Performance of Non-Traditional Exports.

Ghana Export Promotion Council (GEPC), (1989). Action program to address financial constraints affecting export performance and promotion. Draft working paper

Lee, J.W. (1995). 'Capital Goods Imports and Long-run Growth'. Journal of Development Economics 48 (1). p.91-110.

Kalra, Y. (1997). Handbook of reference methods for plant analysis. CRC Press.

Kravis, I. (1970). "Trade as a Handmaiden of Growth: Similarities Between the Nineteenth and Twentieth Centuries". The Economic Journal 80 (2). P.850-872.

Mwega, F. ( 1993). "Import Demand Elasticity's and Stability During Trade Liberalization : A case Study of Kenya ". Journal of African Economics 2(1) , p.381- 416, Oxford University press.

Ngwira, N. (2012). "Drivers of Economic Growth in Malawi", ECAMA Conference Paper. p.239. http://www.rbm.mw/documents/governor_statements/ECAMA_Conference_Presentation.pdf (Accessed on 2/9/2013).

Njikam, O. (2003). 'Exports and economic growth in Sub-Saharan Africa: is there a connection?' University of Yaoundé,

Cameroon. http://www.csae.ox.ac.uk/conferences/2004GPRaHDiA/papers/3fousmanouCSAE2004.pdf\#search='Export s\%20and\%20economic\%20growth \%20in\%20SubSaharan\%20Africa\%3A\%20is\%20there\%20a\%20connec tion $\% 3 \mathrm{~F} \% \mathrm{E} 2 \% 80 \% 99$ (Accessed on 7/10/2013).

Oduro, A., Jebuni, C. D., Asante, Y. \& Tsikata, G. K. (1992). "Diversifying Exports. The Supply Response of Non-traditional Exports to Ghana Institute/University of Ghana.

Ray, D. (1998). Development economics, Princeton, University Press.

Shim J. K. \& Siegel J. G. (1995). "Dictionary of Economics," Untied States of America.

Smith, A. (1776). An inquiry into the nature and causes of the wealth of nations. London: George Routledge and Sons.

World Bank (2008c). 'World Development Indicators 2008', World Bank, Washington. (online) http://data.worldbank.org/sites/default/files/wdi08.pdf (Accessed on 18/6/2013). 